\title{
Multicultural Literature for Building Children's Character
}

\author{
Andarini Permata Cahyaningtyas \\ \{andarinipermata@unissula.ac.id\} \\ Elementary School Teacher Education Department, Universitas Islam Sultan Agung, \\ Jl. Kaligawe Raya Km. 4, Terboyo Kulon, Genuk, Kota Semarang - 50112
}

\begin{abstract}
This paper aims to define the advantages of multicultural literature for building Indonesian children's character. The method is library research, and the data was collected by analyzing journal articles, books, and other scientific sources. The discussion focused on the benefits of multicultural literature in helping parents and teachers teach about five character values: religious attitude, integrity, nationalism, mutual cooperation (gotong royong), and independence. Cap Go Meh, folklore Putri Bidara Putih, Upin Ipin, Battle of Surabaya, and short stories created by the Indonesian Ministry of Education and Culture such as Wisata Kuliner Bersama Nenek, Tiga Pahlawan Tanpa Tanda Jasa, and Dito dan Kisah-Kisah Teladan are some of the Indonesian multicultural stories that will be a good media in teaching and integrating character education values. Hence, parents and teachers should maximize the use of multicultural stories since it is proven to build children's character.
\end{abstract}

Keywords: Multicultural literature; Children's literature; Character education

\section{Introduction}

Indonesia is one of the biggest multicultural countries worldwide that has been successfully maintaining diversity under the national motto "Bhineka Tunggal Ika" or Unity in Diversity. Statistics Center Bureau stated that based on the census held in 2010, Indonesia has 1.340 ethnic groups that live all over the archipelago. Among all of them, Javanese is the largest group, accounting for $41 \%$ of the entire population [1]. With 237.6 million people [2], Indonesia has become the fourth most populous country globally, and 97 thousand of them are Javanese, 36 thousand are Sundanese, and the rest of the groups have only less than $5 \%$ of the population [3]. Among those groups, there are 718 languages spoken as their traditional heritage [4]. Besides, Indonesia has also admitted six religions and permitted the people to choose and worship according to their own beliefs.

The various cultures, languages, religions, and habits of coexistence in differences do not make Indonesian people are free from intolerance, nationalism, and manners problems [5]-[8]. These cases can be bad examples for Indonesian children. They should believe that Indonesia is beautiful because of the diversity and how they should live peacefully in this plural environment. 
To prevent young students from bad attitudes and wrong beliefs, the Indonesian government, through the Ministry of Education, Culture, Research, and Technology, initiated a new program called Strengthening Character Education Movement or Gerakan Peningkatan Pendidikan Karakter (PPK) in elementary and secondary school. This program is part of the "Mental Revolution Movement" (Gerakan Revolusi Mental), a plan established to equalize character education in Indonesia's primary and secondary schools. PPK aims to strengthen students' characters through the harmonization of ethics, aesthetics, literation, and kinesthetic with the support of public involvement and cooperation among school, family, and society [9]. Specifically, PPK is focused on five character values: religious (the attitude of belief in God); integrity (the effort to be a trusted person in words and actions); nationalist (the attitude to put the interests of the nation and the states above their and their group's); mutual cooperation (the effort to respect the spirit of cooperation to solve the problems); and independence (the attitude to be not dependent on others and using the energy, time, and mind to realize dreams and hopes).

PPK will be implemented based on the curriculum structure owned by the school based on the class, school culture, and community [10]. The character values are integrated into the lesson materials, class management, teaching methods, and evaluation in class-based activities. Meanwhile, in school culture-based programs, the headmasters and teachers are role models for students who learn about the values through co-curricular and extra-curricular activities. School culture-based activities can positively affect if conducted by considering students' needs [11]. Lastly, character education is also implemented through society-based strategies that involve the School Committee, parents, education and culture experts and activists, and the regional government. By working together, adults will be able to create a meaningful environment that helps students integrate the values into themselves and live as someone ready to face society. Through those approaches, PPK is expected to help students build and internalize the character values by conducting direct programs, such as administering 5S "Senyum, Salam, Sapa, Sopan, Santun” (Smile, Greeting, and Politeness) [12]; implicating and habituating school culture in religious, health, and arts activities [11]; and managing the classroom through class dealing, class control, and classroom setting [13].

In fact, there are some other ways to teach about character values, including using children's literature. Every possible genre of fiction and nonfiction, novels or comics, poetry or picture books, pop-up books or digital books, animation or movies, are counted as children's literature [14]. By reading or watching them, children will be able to learn unconsciously from the messages conveyed by the writers through the characters and the stories. Children's literature indeed plays a crucial role as an example of "edutainment", something that provides knowledge and entertainment. Moreover, engaging in children's literature will help students improve their language skills, build up a friendly environment, prevent unhealthy habits, and encourage them to live a better lifestyle [15]. Besides, it also helps them to develop a deeper understanding of gender, gender identity, and gender expression [16]. Multiculturalism can also be taught by using children's literature based on diversity in real-life stories, which has been growing throughout these years [17].

The first countries declared to have multicultural societies were Canada, Australia, and the United States. They have a long historical experience of immigration and have been built up out of immigration. Then, Europe was also known for its racial/ethnic/religious mix in some urban centers in the southern area [18]. By the 1980s, multiculturalism was referred to "not dominated by whites", but there was controversy because people debated who is included in the term "multi" [17]. Multiculturalism contains two complex meanings: "multi", which is plural, and "culturalism", which means culture. The plural term is interpreted as various 
because pluralism is about acknowledging various things and the principle of democracy in politics, society, and the economy [19]. Thus, multicultural literature can include stories about people from diverse cultural, linguistic, socioeconomic, and religious backgrounds; also involved issues on gender and disabilities [20]. On the other hand, understanding multiculturalism as cheek by jowl causes some people to live close to each other or in a neighborhood. However, they have different beliefs, acts, habits, and physical appearances. This will affect them positively and negatively. Positively, they can fulfill their needs more leisurely. Otherwise, if the majority and the minority can not adapt to each other, they will face conflicts [21].

For children in primary school age, comprehending such an abstract thing as multiculturalism and diversity is problematic. They need concrete examples that happen in real life as they are still in the concrete operational stage. Based on Piaget's cognitive theory, children in that phase can learn from their experience rather than be swayed by what they perceive [22]. Indonesian kids who have been members of a plural society and got the firsthand experience since they were born actually will understand the concept of diversity and multiculturalism better than those who grow up in a homogeneous environment. Even so, children will only understand plurality that exists in their surroundings. How about other cultures, religions, or ethnicities that cannot be found in their family or neighborhood? For example, children who live in Java predominantly Muslim and Javanese ethnic could face difficulties accepting Christian kids from Papua since never been in contact with them before.

Children's literature will be the best way to be implemented in elementary school to help them compare and contrast information, educate questions, analyze evidence, and predict things. Furthermore, they may become more aware and empathetic in their responses to people and events they never experienced before [23]. Multicultural characters and diverse historical and international contents will also teach them to recognize their and others' beliefs, traditions, and values [24]. So, it can be concluded that by using children's literature, teachers and parents can provide them with information about pluralism they cannot find in their surroundings. This is also effective for them in putting themselves in others' shoes and preventing them from having extreme thoughts about people different from them.

Given the reality, children's literature is proven to be a good and wise tool to enhance student's character. However, recent studies in Indonesia show that the literature used in elementary school to build student's character has not been specified in multiculturalism context and only reviews children's literature in general [25]-[27]. Hence, to obtain a deeper insight into how multicultural literature can help Indonesian children to build their characters, this study will be conducted to find the benefits of multicultural context in children's literature for building children's character.

\section{Method}

This study used a literature review to answer the research question. A literature review is a written document that presents a logically argued case founded on credibility based on previous research. It provides the context and the background about the current knowledge of the topic and lays out a logical case to defend the thesis position was taken [28]. There are six steps to conduct a literature review: 1) select a topic; 2) search the literature; 3) develop the argument; 4) survey the literature; 5) critique the literature; and 6) write the review.

The topic must be stated as a well-defined statement that needs to be specified and focused. Then, search the literature that can support the argument using skimming, scanning, 
and mapping skills. After the literature was collected, the data needed to be cataloged and documented. The findings also have to be arranged logically and explained about what is known about the topic. Next, the literature needs to be assembled, organized, and analyzed to set a conclusion. The data, then, is interpreted and used to justify the thesis statement. Finally, through composting and refining, the literature review is written to convey the research accurately. These steps require writing, auditing, and editing the composition.

\section{Result and Discussion}

\subsection{Result}

Multicultural literature contains stories that show diversity in religion, culture, and language and how society can coexist peacefully. For children, multicultural literature equips them with an understanding of the issues that drive our society and how to be effective change agents. The way teachers use multicultural literature can help them see value in both differences and similarities between and among people. More importantly, it can open the door to helping them understand social justice issues, become acquainted with multiple perspectives, and gain insight into their own cultures [29]. In teaching character education, multicultural literature can be one of the tools to convey what kind of person children need to be, including the character education that the government expects Indonesian children to have.

\subsubsection{Religious Attitude}

The religious attitude is the first character value that Indonesian children should have because it is a country that believes in God and admits six religions (Islam, Catholic, Christian, Hindu, Buddha, and Konghucu). This is clearly stated in the first precept of Pancasila, Ketuhanan Yang Maha Esa. In PPK, the character of being religious is shown in carrying out the dogma, respecting religious differences, upholding a tolerant attitude towards the implementation of religious worship, and living in peace with others who have different beliefs. This character encompasses three dimensions of life: the relationship between humans and God, among human beings, also between humans and the environment. These relations are reflected in the attitude of loving peace, tolerance, respecting each other, having strong determination, working together without differentiating religions, anti-bullying and violence, friendship, sincerity, and protecting the minority [10].

Moreover, there is no majority or minority terms in human rights matter. In the 1945 Constitution article 29 paragraph 2, the Indonesian government has also guaranteed the citizen's religious freedom. Thus, multiculturalism has become a concept that children need to be taught from an early age, and literature will help parents deliver good messages. Besides, using multicultural literature at school will also encourage children to be engaged in the idea of mutual recognition and appreciation for one another inside the classroom and toward others beyond the classroom [30], regardless of the difference they might have and gain awareness to respect people in a more diverse environment.

For example, a story for children called Cap Go Meh talked about two children from different cultures. Nisa, a little Muslim girl, has a close friend named Lily, a Chinese. The story leads to their experience celebrating Lebaran Kupatan as a part of Eid Al-Fitr and Chinese New Year (Cap Go Meh). At the first time, they argued whether lontong is the specialty of Muslims in Lebaran Kupatan or Chinese in Cap Go Meh. Then, after they tell 
each other about how they celebrate their religious celebration, both of them conclude that they should not make a fuss about the difference in their religion and cultures. Each of them has its uniqueness, and they just need to respect each other. By reading this kind of story, they will understand about lontong Cap Go Meh and the cultural background of the Chinese New Year celebration, and there is a possibility of adaptation if two different cultures meet [31].

\subsubsection{Integrity}

The second is integrity, an underlying value behavior to be someone who can be trusted in words and actions, have a commitment and faith to humanity and morality. This includes being responsible as a citizen, active in social relations, and consistent in truth. These actions can be shown in honesty, faithfulness, anti-corruption, fairness, responsibility, exemplary, and respecting individual dignity (especially for person with disabilities) [10].

Basically, multicultural literature is tricky to define as it includes the literary writing of groups of people from different races, colors, values, and cultures [32]. The relation among the various characters in the story can be an example for children to be a person who respects humanity in social relations. In terms of social relationships with persons with disabilities, children need to understand that they should not discriminate against them based on their drawbacks because a wrong understanding of disability will cause such a possibility for someone to be involved in bullying cases. However, it can be minimized by strengthening multicultural, and character education [33], and multicultural literature can educate children about both concepts.

Moreover, learning about multiculturalism through literature will allow children to understand that as a part of a plural community, they are responsible for being respectful, fair, and honest. As the result of the research, multicultural literature has been proven to be able to facilitate children to learn about contemporary culture and characteristics of other races and demonstrate some examples of racism, culture, and colorblindness; provide them with a valuable opportunity to think critically about the issue of discrimination, racial justice, and social justice; and help them to develop some advanced vocabularies, such as freedom, injustice, equity, and equality [34], [35].

For instance, the Christian children's book Davey Panda, created by Myra G. Love, tells about a panda in a wheelchair who wants to learn to ride a bicycle. His friends looked down on him initially, even laughed at him. However, after trying and praying so hard, he finally rode the bicycle, and his friends recognized his ability and didn't underestimate him anymore [36]. There was a research that developed interactive children book about children with disabilities. The book was created to deliver knowledge about disabled people, so children will understand and care more about people with disabilities [37]. Both stories can be an example for children to be fair and active in social relations and respect every individual dignity regardless of their disabilities.

\subsubsection{Nationalism}

Next is nationalism. This value includes a way of thinking and acting that shows faithfulness; concern; high appreciation of languages, physical environment, social, cultural, economic, and politics; and putting the states' interest above their selves and groups. The subvalues of nationalism appreciate our own cultures, preserving the nation's cultural wealth, being willing to sacrifice, loving the country, protecting the society, obeying the law, discipline, and respecting diversity [10]. 
In fact, Indonesia is a multicultural country, and children might have become a multicultural community since they were born. In Indonesia, it is common to marry someone from another ethnic group, and parents can affect what languages and how many languages their children will master [38]. Two different cultures and languages will adapt to each other, and mostly, this multicultural family will rely on Indonesian as the primary language among the family members, though they still use their traditional languages. Children need to understand that being an Indonesian means being ready to be a part of the multicultural community and having an ethnic identity. Ethnic identity is defined as the attitude when individuals appreciate and actively engage in their own cultural values, traditions, beliefs, and behaviors [39]. This means someone still has to be proud of their identity as a part of an ethnic group, but as a citizen, they should also love the country, comply with the law, and think about the nation's interests before theirs.

Furthermore, in teaching ethnic identity, adults (parents and teachers) should integrate it into multicultural education because separating it will only cause the marginalization of minority groups [40]. To avoid it, teachers and parents can use multicultural literature to convey the message about nationalism value, and children will be able to comprehend both concepts as a whole. Thus, ethnic, racial, religious, social class, language, and cultural boundaries can be embodied in multicultural literature, and it can be a robust literary material in developing and strengthening people's nationalism [41].

One Indonesian multicultural literature that put nationalism as the message of the stories is Putri Bidara Putih. The folklore comes from East Kalimantan, which tells about two different cultures, Chinese and Kalimantan. The setting of the stories is indeed in the royal era before Indonesia's independence. Still, it showed that they had had the spirit of loving their country since a long time ago, and that spirit should be preserved and implicated in recent days [42]. The story will be good literature for children in learning and integrating nationalism value into their selves.

\subsubsection{Mutual Cooperation}

Gotong royong or mutual cooperation is a trait of Indonesian people who respect the spirit of collaboration, solve the problem, establish communication and friendship, and help the people in need. The sub-values are respect, cooperation, commitment to joint decisions, deliberation, mutual help, solidarity, empathy, anti-discrimination, anti-violence, and volunteerism [10].

Through multicultural literature, children will learn how to empathize with children from underrepresented cultures and beliefs [43]. Therefore, learning to empathize is a good start for children in understanding and respecting others. Empathizing is not only about entailing the calculation of what someone thinks and feels, but it is also about having an appropriate emotional reaction triggered by the other person's emotion to understand others, predict their behavior, and connect with them emotionally [44]. Thus, children will try to put themselves in someone else's shoes before giving comments or judgment regarding someone's belief or culture, believing that they should not have prejudice about a particular culture regardless of its position as the majority or minority. All of those will lead them into the concept of respect, collaboration, solidarity, anti-discrimination, and anti-violence.

On the one hand, mutual cooperation is also a part of one of the local wisdom values, wellbeing [45]. Local wisdom is a cultural embodiment, so the values do not differ from the effect of local cultures [46]. Mutual cooperation is a character value that has become a characteristic of Indonesian people. The development of bilingual children's books containing Semarangan 
culture has been an example of the effort in providing multicultural literature for children with mutual cooperation as one the message of the story. Semarangan culture was chosen as it comes from three diffused cultures, Chinese, Arabian, and Javanese. Moreover, this book uses Javanese and Indonesian as the languages. Javanese was also chosen since the use of traditional language has been starting to decrease a lot [47]. This kind of literature will help society preserve the local wisdom, culture, and languages and prevent them from extinction since international culture has dominated nowadays people a lot.

\subsubsection{Independence}

The last character value is independence. Independent is an attitude and behavior to not depend on other people and use our energy, mind, and time to realize hopes and goals. Specifically, independence is divided into several sub-values: hard work, resilience, professional, creative, brave, and lifelong learning [10].

Research stated that "one way to bring character education into a crowded curriculum is to make it part of the literacy program by embedding character lessons in reading and language arts instruction through the vehicle of high-quality children's literature" [48]. As Indonesian a multicultural community, multicultural literature will be an excellent way to introduce character education, including the independent value. This is proven by a statement that characteristics of multicultural literature include people of color in the position of power, females being portrayed as smart, strong, and independent, and different group of people helping their own, not just the majority [49] will teach children to be more confident with their selves, and be independent regardless of gender.

For example, Upin Ipin is a representation of the multicultural community in Malaysia. Nevertheless, Indonesian children also watch this animation series a lot. In the story, there is a character called Meimei, who is a little Chinese girl. She is represented as diligent, competent, and hard work. She never misses completing the homework and also helps her mother at home [50]. Children who watch Upin Ipin will learn to be hard workers just like Meimei who can balance her educational life and her life as a family child.

\subsection{Discussion}

Each of those five character values does not stand alone but interacts with each other and develops dynamically to form a whole character. Religious attitude is a value that shows faith in God, and it becomes the fundamental value for a human to interact with The Almighty and other people. In social life, religious value merges in nationalism, independence, mutual cooperation, and integrity [10]. This can be seen from the results above that religious people tend to be respectful towards diversity, tolerance, sincere, and willing to work together with those who do not have the same belief. Someone can have those attitudes because they can understand how others think and feel and put themselves in other people's shoes. It is called empathy, one of the sub-values in implementing mutual cooperation. Besides, to maintain mutual cooperation, someone needs to show solidarity and anti-discrimination, which are the basic attitudes to adapt and survive in a multicultural society, such as Indonesia. Even the number of members of ethnic groups and believers in Indonesia is different. The majority and minority people still have the same rights and responsibilities in front of the law. They have to put the state's interests above their groups' to prove their nationalism and integrity. Lastly, besides being part of a group and country, someone must also be working hard, professional, resilient, creative, and willing to learn continuously to improve their skills and knowledge. 
The internalization of the character values and multiculturalism cannot be conducted by binding a doctrine system. It must be performed in various ways, such as using literature that contains such a familiar story for the children [51]. Meanwhile, authors of multicultural literature for children are acting as cultural messengers. Still, they may unconsciously impose their own cultural beliefs and values on the culture they try to recreate, exhibit and locate in any fictional texts [32]. Hence, parents and teachers need to be selective in choosing multicultural literature for children because it must be suitable for their age, characteristics, and cultures and encompass accurate and authentic cultural representation. Cultural accuracy refers to the truthfulness of the represented facts about a culture or cultural group, while cultural authenticity refers to the trustworthiness of the represented cultural nuances [52]. Both are important since children will learn and comprehend the messages from the literature. If the stories' content is not accurate and authentic in representing a culture, religion, or society's habit, then there will be misunderstandings.

Moreover, there are some criteria to help adults selecting good multicultural literature: 1) characters should be authentic, not stereotyped; 2) characters should be balanced in physical, social, and emotional attributes; 3 ) the setting should be consistent with either historical or contemporary time frame; 4) the themes and values should be consistent with the specific culture depicted; 5) the illustrations, gender roles, and information about the culture should be accurate; 6) the selection should be rich in cultural details; 7) the selection should include an authentic interaction between characters with a cultural group or between two or more cultural groups; there should be a purpose for including members of a "minority" group, not just to fill a quota of sorts; 9) the selection should invite reflection, critical analysis, and response, and 10) the selection should meet the generally accepted criteria of quality for the particular genre in which it is written [53]. With these criteria, parents and teachers will be able to high-quality literature in teaching multiculturalism that will lead them into an understanding of character education which becomes the message of multicultural literature.

As mentioned before, Indonesian multicultural literature mainly contains various values of character education. For instance, the Battle of Surabaya is an adaptation of the November 10, 1945 war in Surabaya. The main character is Musa, a shoeshine craftsman who gets the mission to become a secret message sender to Indonesian soldiers and militia fighters. Together with his friends, Yumna, a Christian girl, and Danu, who joins them in protecting Indonesia from the invaders, Musa experienced various events that made him lose his beloved person. This film contains five-character values as one of its messages [54]. It also teaches children to be grateful because now, they live in a secure environment, thanks to our heroes who gained and protected Indonesia's independence several decades ago.

On the one hand, Ministry of Education and Culture has issued several multicultural short stories that contains character education and are accessible for children, such as Tiga Pahlawan Tanpa Tanda Jasa by Faturrahman Arroisi and Wida Ayu P., Wisata Kuliner bersama Nenek by Unsiyah Anggraeni and Septinata C.P., and Dito dan Kisah-kisah Teladan by Fitria Nia Dikasari and Titin Indriarti [51]. These stories encompass religious attitudes, independence, and nationalism values. All of those stories are appropriate for elementary students, but Wisata Kuliner Bersama Nenek is more suitable for lower graders, while Tiga Pahlawan Tanpa Tanda Jasa and Dito dan Kisah-kisah Teladan are more proper for upper graders.

Parents and teachers share the same duty regarding the responsibility of providing facilities and guiding children in learning multiculturalism. Even though teachers can be an essential source of information about the available literature [55], the influence of family on children's attitude about and knowledge of other cultures cannot be overstated [56] to create a closer 
integration of the activities in school to eliminate the phenomenon of separation between school and the outside world [57]. In 4.0. Era, parents should not experience any tough challenges in finding high-quality multicultural literature. By considering the criteria mentioned above and accessing the internet, they will find suitable reading resources for their kids.

Meanwhile, at school, teachers can be examples for children in understanding the concept of multiculturalism and how to act according to character values. To successfully reach the stage, the teacher education program should use literature to facilitate the students' conversations and understandings of how their beliefs, biases, and prejudice impact teaching [58]. Preparing preservice teachers to develop into culturally responsive teachers also positively impacts their skills in teaching diverse students with multicultural literature as a tool [59], [60]. This is important for Indonesian teachers because most of them have a big chance to teach children from various religious and social backgrounds.

When multicultural literature is utilized in a meaningful way, and when teachers use it with a positive attitude, multicultural literature can be an excellent medium to enhance the learning experience for children and teachers [60]. Furthermore, reading multicultural literacy will also develop children's critical literacy and social awareness [30]. This shows that multicultural literature is effective in teaching multiculturalism and character education and building the experience and awareness of the children. Hence, this study suggests that parents and teachers will facilitate children with multicultural literature more since it has been proven that it benefits them in many ways.

\section{Conclusion}

Based on the result, teachers and parents have been actively supporting the program in various ways since the Indonesian government issued the PPK program to strengthen character education for elementary and secondary students. One of the practical tools is by using multicultural literature. This kind of literature is suitable for Indonesian children to learn multiculturalism as they have become a part of a multicultural community since they were born. Moreover, the stories about multiculturalism are also proven to contain character education values as its messages. Cap Go Meh, folklore Putri Bidara Putih, Upin Ipin, Battle of Surabaya, and short stories created by the Indonesian Ministry of Education and Culture such as Wisata Kuliner Bersama Nenek, Tiga Pahlawan Tanpa Tanda Jasa, and Dito dan Kisah-Kisah Teladan are some of the Indonesian multicultural stories that will be a good media in teaching and integrating character education values. In addition, multicultural literature is also productive to enhance students' and teachers' learning experiences and build

critical literacy and social awareness. In conclusion, parents and teachers should maximize multicultural literature since it brings advantages in many aspects.

\section{Acknowledgments}

I would like to thank Universitas Islam Sultan Agung, that allowed me to join the conference and publish this article. I hope this paper will be helpful to those who study the topic of multicultural education and character education specifically and elementary education generally. 


\section{References}

[1] "Suku Bangsa," Portal Informasi Indonesia, 2017. https://indonesia.go.id/profil/sukubangsa/kebudayaan/suku-bangsa (accessed Jun. 15, 2021).

[2] A. Ananta, E. Nurvidya Arifin, and M. Sairi Hasbullah, "Demography of Indonesia's Ethnicity," Demogr. Indones. Ethn., no. November, 2018, doi: $10.1355 / 9789814519885$.

[3] "Mengulik Data Suku di Indonesia," Central Bureau of Statistics, 2015. https://www.bps.go.id/news/2015/11/18/127/mengulik-data-suku-di-indonesia.html (accessed Jun. 15, 2021).

[4] "Daftar Bahasa-bahasa Daerah di Indonesia," Laboratorium Kebinekaan Bahasa dan Sastra, 2021. https://labbineka.kemdikbud.go.id/bahasa/daftarbahasa (accessed Jun. 15, 2021).

[5] D. Ihsan, "Kumpulan Kasus Intoleransi di Sekolah,” Kompas, 2021.

[6] V. K. M. Putri, "Etnosentris: Pengertian, Penyebab, Dampak dan Contoh Sikapnya," Kompas, Apr. 16, 2021.

[7] Murni, "Hilangnya Rasa Hormat Siswa Kepada Guru," Serambi News, Sep. 27, 2019.

[8] Wahyono, "Sejumlah Gerakan Separatis di Indonesia," Sindo News, Dec. 02, 2019.

[9] Kemendikbud, Gerakan Penguatan Pendidikan Karakter (PPK) [Infographics of the Strengthening Character Education Movement]. Jakarta: Kemendikbud, 2017.

[10] Kemdikbud, Kajian dan Pedoman Penguatan Pendidikan Karakter (PPK). 2016.

[11] E. Labudasari and E. Rochmah, "Peran budaya sekolah dalam meningkatkan karakter siswa sekolah dasar," in Seminar Nasional Prodi PGSD-FKIP Universitas Muhammadiyah Purwokerto, 2018, pp. 299-310.

[12] D. N. Khotimah, "Implementasi program Penguatan Pendidikan Karakter (PPK) melalui kegiatan 5s di sekolah dasar," Inopendas J. iImiah Kependidikan, vol. 2, no. 1, pp. 28-31, 2019, [Online]. Available: https://jurnal.umk.ac.id/index.php/pendas/article/view/2928.

[13] D. R. R. Yuliana, S. Hawanti, and O. Wijayanti, "Pelaksanaan Program Penguatan Pendidikan Karakter (PPK) Berbasis Kelas Melalui Manajemen Kelas di Sekolah Dasar," J. Temat., vol. 9, no. 2, pp. 109-114, 2016, doi: https://doi.org/10.24114/jt.v9i2.14434.

[14] V. de Rijke, "Reading children's literature," Educ. 3-13, vol. 49, no. 1, pp. 63-78, 2021, doi: 10.1080/03004279.2020.1824703.

[15] M. Pulimeno, P. Piscitelli, and S. Colazzo, "Children's literature to promote students' global development and wellbeing," Heal. Promot. Perspect., vol. 10, no. 1, pp. 13-23, 2020, doi: 10.15171/hpp.2020.05.

[16] K. Elson and K. Nash, "Taking a journey to the land of all: Using children's literature to xxplore gender identity and expression with young children," Occas. Pap. Ser., vol. 2020, no. 44, p. 4, 2020.

[17] D. L. Gilton, Multicultural and Ethnic Children's Literature in the United States, Second Edi. London: Rowman \& Littlefield, 2020.

[18] T. Modood, Multiculturalism. Cambridge: Polity Press, 2007.

[19] H. A. R. Tilaar, Tantangan-tantangan Global Masa Depan dalam Transformasi Pendidikan Nasional. Jakarta: Grasindo, 2004.

[20] J. Yokota, Kaleidoscope: A Multicultural Booklist for Grade K-8. Urbana: National Council of Teachers of English, 2001.

[21] Z. Baidhawy, Pendidikan Agama Berwawasan Multikultural. Jakarta: PT. Gelora 
Aksara Pratama, 2005.

[22] D. H. Schunk, Learning Theories: An Aducational Perspective, Sixth Edit., vol. 71, no. 1-4. Bosto: Pearson Education Inc., 2012.

[23] C. Newstreet, A. Sarker, and R. Shearer, "Teaching Empathy: Exploring Multiple Perspectives to Address Islamophobia Through Children's Literature," Read. Teach., vol. 72, no. 5, pp. 559-568, 2019, doi: 10.1002/trtr.1764.

[24] J. Dewilde and T. A. Skrefsrud, "Including alternative stories in the mainstream. How transcultural young people in Norway perform creative cultural resistance in and outside of school," Int. J. Incl. Educ., vol. 20, no. 10, pp. 1032-1042, 2016, doi: 10.1080/13603116.2016.1145263.

[25] N. Saputra, "Pembentukan nilai pendidikan karakter melalui pembelajaran bahasa dan sastra indonesia di sekolah dasar," in Prosiding Konferensi Ilmiah Dasar, 2020, vol. 2, pp. 388-398.

[26] N. Solihati, A. Hikmat, and A. R. Eka, "Pelatihan penguatan karakter melalui sastra anak dalam pembelajaran Bahasa Indonesia bagi gGuru di SDN Gandasari 02 Kabupaten Bekasi," in Prosiding Seminar Nasional Abdimasmu, 2021, vol. 2, no. 1, pp. 34-41.

[27] D. Swandayani, "Sastra sebagai dasar pendidikan karakter bangsa," in Seminar Nasional "Pengajaran Bahasa Asing dan Pendidikan Karakter," 2011, no. November, pp. $1-11$.

[28] L. A. Machi and B. T. McEvoy, The Literature Review: Six Steps to Success, Second Edi. Thousand Oaks: Corwin, 2012.

[29] R. Robinson, "Multicultural and Global Children's Literature as Agents of Change," Handb. Res. Media Lit. Res. Appl. Across Discip., pp. 90-100, 2019, doi: 10.4018/9781-5225-9261-7.ch006.

[30] E. Morrell and J. Morrell, "Multicultural readings of multicultural literature and the promotion of social awareness in the ELA classrooms," New Engl. Read. Assoc. J., vol. 47, no. 2, pp. 10-16,81, 2012.

[31] R. Djumala, "Multikulturalisme dalam bacaan anak Indonesia," in Proceedings Literary Studies Conference, 2017, pp. 119-123.

[32] K. Bista, "Multicultural literature for children and young adults," Educ. Forum, vol. 76, no. 3, pp. 317-325, 2012, doi: 10.1080/00131725.2012.682203.

[33] P. S. Utami, "Integrasi pendidikan multikultural dan penguatan nilai karakter siswa sebagai upaya penanganan kasus bullying pada anak difabel," 2016.

[34] K. Bailey and M. Duthoo-Wolpert, "Teaching race through multicultural children's literature," University of Northern Iowa, 2021.

[35] S. J. Kim, S. J. Wee, and Y. M. Lee, "Teaching kindergartners racial diversity through Multicultural literature: A case study in a kindergarten classroom in Korea," Early Educ. Dev., vol. 27, no. 3, pp. 402-420, 2016, doi: 10.1080/10409289.2015.1069110.

[36] C. Nilawaty, "Davey Panda, Buku Anak Dengan Tokoh Utama Penyandang Disabilitas,” Tempo, Jan. 04, 2019.

[37] Y. Kencanasari, H. Aryanto, A. Christianna, D. K. Visual, F. Seni, and U. K. Petra, "Perancangan buku interaktif tentang anak disabilitas," J. DKV Adiwarna, vol. 1, no. 14, pp. 1-9, 2019.

[38] A. P. Cahyaningtyas, Bahasa Anak: Memahami Perkembangan Anak dari Sudut Pandang Bahasa. Semarang: Beruang Cipta Literasi, 2020.

[39] D. Nesdale, R. Rooney, and L. Smith, "Migrant ethnic identity and psychological distress," J. Cross. Cult. Psychol., vol. 28, pp. 569-589, 1997. 
[40] Y. M. Chang, “Teachers' perspectives: Making sense of ethnic nationalism, ethnic identity and multicultural education in South Korea," Int. J. Educ., vol. 7, no. 2, p. 17, 2015, doi: 10.5296/ije.v7i2.7018.

[41] A. M. Ali Imron and F. Nugrahani, "Strengthening pluralism in literature learning for character education of school students," Humanit. Soc. Sci. Rev., vol. 7, no. 3, pp. 207213, 2019, doi: 10.18510/hssr.2019.7332.

[42] Y. Herawati, "Nasionalisme dalam cerita rakyat Kalimantan Timur (Pemetaan dan kajian sastra daerah)," in Kongres Bahasa Indonesia, 2018, no. 1, pp. 1-19.

[43] S. A. Colby and A. F. Lyon, "Heightening awareness about the importance of using multicultural literature," Multicult. Educ., vol. 11, no. 3, pp. 24-28, 2004.

[44] B. Chakrabarti and S. Baron-Cohen, "Empathizing: neurocognitive developmental mechanisms and individual differences," Prog. Brain Res., vol. 156, pp. 403-417, 2006, doi: 10.1016/S0079-6123(06)56022-4.

[45] R. Sibarani, Kearifan Lokal: Hakikat, Peran, dan Metode Tradisi Lisan. Jakarta: Asosiasi Tradisi Lisan, 2012.

[46] T. W. Septarianto, "Manifestasi nilai-nilai kearifan lokal dalam buku cerita anak KecilKecil Punya Karya (KKPK) 'Lili \& Lyliu,"' in Seminar Internasional Riksa Bahasa XII, 2018, pp. 829-836.

[47] R. R. Utami, N. I. Putri, and C. Nugraha, "Buku pengayaan cerita anak dwi bahasa bermuatan budaya Semarangan: Potensi dan prinsip pengembangannya," J. Pendidik. Bhs. Indones., vol. 6, no. 1, pp. 65-74, 2018.

[48] G. M. Almerico, "Building character through literacy with children's literature," Res. High. Educ. J., vol. 26, pp. 1-13, 2014.

[49] H. Morgan, "Using read-alouds with culturally sensitive children's books: A strategy that can lead to tolerance and improved reading skills," Read. Improv., vol. 46, no. 1, pp. 3-9, 2009.

[50] E. Syam, Q. I. Aris, and V. Amelia, "Representasi masyarakat Malaysia yang multikultural dalam kisah 'Upin dan Ipin,'” Pros. Semin. Nas. Cendekiawan, vol. 5, pp. 2.71.1-2.71.7, 2019, doi: 10.25105/semnas.v0i0.5870.

[51] G. Assidik and F. Dianastiti, "Does multiculturalism-based literary appreciation with CLIL approachable to reinforcement character education for student?," 2020, doi: 10.4108/eai.12-10-2019.2292202.

[52] T. M. Haghanikar, "The Ethnicity of the Implied Author and the Implied Reader in Multicultural Children 's Literature," CLELE J., vol. 8, no. 1, pp. 10-30, 2020.

[53] J. Yokota, "Issues in selecting multicultural children's literature," Lang. Arts, vol. 70, no. 3, pp. 156-167, 1993.

[54] A. P. Cahyaningtyas, R. F. Kusumadewi, and K. A. Al Maskuri, "Battle of Surabaya: Promoting character values throuh animated movie," in The 2019 International Conference of Sustainability Issues in Social Science, Business, Management, \& Information Technologi (I-COSBIT), 2019, pp. 175-182.

[55] S. M. Landt, "Multicultural Literature and Young Adolescents: A Kaleidoscope of Opportunity," J. Adolesc. Adult Lit., vol. 49, no. 8, pp. 690-697, 2006, doi: 10.1598/jaal.49.8.5.

[56] J. Pattnaik, "Multicultural literacy starts at home: Supporting parental involvement in multicultural education," Child. Educ., vol. 80, no. 1, pp. 18-24, 2003, doi: 10.1080/00094056.2003.10521245.

[57] F. Smit and G. Driessen, "Parents and schools as partners in a multicultural, multireligious society," J. Empir. Theol., vol. 20, no. 1, pp. 1-20, 2007, doi: 
$10.1163 / 157092507 \times 188557$.

[58] S. V Bennet, A. A. Gunn, K. van Beynen, and M. Lou Morton, "Religiously diverse multicultural literature for early childhood," Early Child. Educ. J., pp. 1-11, 2021, doi: 10.1007/s10643-021-01180-7.

[59] Y. Iwai, "Culturally responsive teaching in a global era: Using the genres of multicultural literature," Educ. Forum, vol. 83, no. 1, pp. 13-27, 2019, doi: 10.1080/00131725.2018.1508529.

[60] S. L. Osorio, "Multicultural literature as a classroom tool," Multicult. Perspect., vol. 20, no. 1, pp. 47-52, 2018, doi: 10.1080/15210960.2018.1408348. 